Western University Scholarship@Western

Aboriginal Policy Research Consortium International (APRCi)

4-2010

\title{
Market Forces and Indigenous Resistance Paradigms
}

Maggie Walter

Follow this and additional works at: https://ir.lib.uwo.ca/aprci

Part of the Other Public Affairs, Public Policy and Public Administration Commons, and the Other Sociology Commons

Citation of this paper:

Walter, Maggie, "Market Forces and Indigenous Resistance Paradigms" (2010). Aboriginal Policy Research Consortium International (APRCi). 367.

https://ir.lib.uwo.ca/aprci/367 
This article was downloaded by: [University of Western Ontario]

On: 18 November 2012, At: 07:58

Publisher: Routledge

Informa Ltd Registered in England and Wales Registered Number: 1072954 Registered

office: Mortimer House, 37-41 Mortimer Street, London W1T 3J H, UK

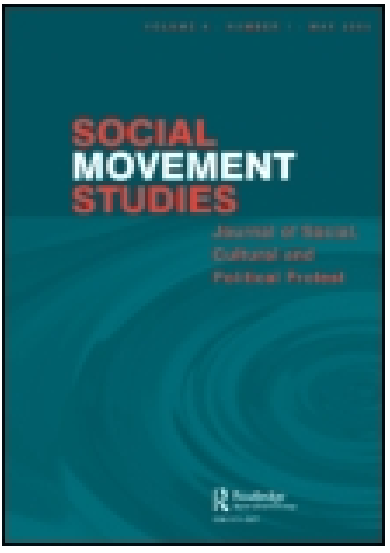

\title{
Social Movement Studies: J ournal of Social, Cultural and Political Protest
}

Publication details, including instructions for authors and subscription information:

http:// www.tandfonline.com/loi/ csms20

\section{Market Forces and Indigenous Resistance Paradigms}

\author{
Maggie Walter ${ }^{\text {a }}$ \\ a University of Tasmania, Hobart, Australia \\ Version of record first published: 17 Mar 2010.
}

To cite this article: Maggie Walter (2010): Market Forces and Indigenous Resistance Paradigms, Social Movement Studies: J ournal of Social, Cultural and Political Protest, 9:2, 121-137

To link to this article: http:/ / dx.doi.org/ 10.1080/ 14742831003603273

\section{PLEASE SCROLL DOWN FOR ARTICLE}

Full terms and conditions of use: http://www.tandfonline.com/page/terms-and-conditions

This article may be used for research, teaching, and private study purposes. Any substantial or systematic reproduction, redistribution, reselling, loan, sub-licensing, systematic supply, or distribution in any form to anyone is expressly forbidden.

The publisher does not give any warranty express or implied or make any representation that the contents will be complete or accurate or up to date. The accuracy of any instructions, formulae, and drug doses should be independently verified with primary sources. The publisher shall not be liable for any loss, actions, claims, proceedings, demand, or costs or damages whatsoever or howsoever caused arising directly or indirectly in connection with or arising out of the use of this material. 


\title{
Market Forces and Indigenous Resistance Paradigms
}

\author{
MAGGIE WALTER \\ University of Tasmania, Hobart, Australia
}

\begin{abstract}
The pervasive force in the relationship between the nation-state and Australian Indigenous peoples during the 1990s and 2000s was, and is, neoliberalism. Free market ideals became the dominant political philosophy and Indigenous people were coerced into a political 'experimental' cutting of a neoliberal template into the fabric of Indigenous life. The pairing of market ideology with concerted efforts to de-power Indigenous groups and people align, at least thematically, the Indigenous experience of neoliberalism with that of a social movement. This article details the entwined story of explicit Indigenous resistance and activism and the how and what of the infiltration of market forces into Aboriginal territory. Empirically, it demonstrates the neoliberal infrastructure and ideological rationale for the explicit undermining of Indigenous rights and presence within Australian society and the Indigenous parameters of resistance that emerged to confront and defy the re-confining and redefining pressures of neoliberalism: an Indigenous resistance paradigm. Theoretically, these facets are analysed through the frame of the 'domain of Aboriginality' to articulate the broader contours of the reach of neoliberalism into Indigenous lives and the resistance to the developing hegemony.
\end{abstract}

KeY Words: Activism, Indigenous, Northern Territory Intervention, public policy, social movement, social position

\section{Introduction: Enter the Neoliberal 'Phase'}

The Australian Indigenous population, ${ }^{1}$ itself made up of the many different Aboriginal and Torres Strait Islander peoples, form 2.5 per cent of the total, or just over 500,000 people. Nearly three-quarters of us live alongside our non-Indigenous counterparts in urban and regional areas but, regardless of location, we remain embedded at the bottom of the Australian social hierarchy. We are the poorest (by far), the least employed (by far), the least educated or advantaged across socio-economic realms and our burden of preventable ill-health and premature death is overwhelming. Indigenous Australians also do not have any direct political representation and since the closing down of the Aboriginal and Torres Strait Islander Commission (ATSIC) in 2005 (explored within this article) have no national representative organization. We are also under-represented to the point of complete absence from all spheres of influence within Australian political, economic and social life.

Correspondence Address: Maggie Walter, Senior Lecturer, Sociology and Social Work, PB 17, University of Tasmania, Hobart 7000, Australia. Email: margaret.walter@utas.edu.au 
The relationship between the state and Australian Indigenous peoples has always been conflictual. Since the colonial declaration of Australia as terra nullius, or empty land, allowed the violent, but legalized, eviction of Indigenous populations from land deemed 'settled', the nation-state has deployed coercive power to ensure its will prevails. The pervasive force in this relationship during the 1990s and 2000s was, and is, neoliberalism. Free market ideals became the dominant political philosophy and Indigenous people the unwilling participants in an 'experiment' attempting to enforce a neoliberal template on the fabric of Indigenous life. Discourses of the free market were the central pillar around which Indigenous issues (irremediably caste as 'problems') were defined. Indigenous-specific rights, culture and place were deemed ideologically unpalatable and were explicitly undermined and negated.

Australian Indigenous peoples are not, of course, a definable social movement. Rather, it is the pairing of market ideology with concerted efforts to de-power Indigenous groups and people that align the Indigenous experience of neoliberalism with that of a social movement. Neoliberal ideologies, policies and practices undermined our rights throughout the nation, but the struggle was (is) the purview of multiple legitimate, often disparate, Indigenous voices, opinions and strategies. Nor are Australian Indigenous peoples homogeneous. It is as Walpiri, Pakana, Yorta Yorta and many other peoples that we primarily identify, and the shape and context of our struggles are bounded by that belonging. Yet within this diverse space is a shared commitment to Indigenous sovereignty, culture and place and resistance to efforts to restrain these. And neoliberalism was an explicit threat, requiring specific and unique resistances to what were a specific and unique group of economic and political interests ranged against Indigenous rights.

\section{Indigenous Resistance Paradigms}

This article details the entwined story of explicit Indigenous resistance and activism and the how and what of the infiltration of market forces into Aboriginal territory. What emerged were new Indigenous parameters of battle against the re-confining and redefining pressures of neoliberalism: an Indigenous resistance paradigm. The theoretical framework analysing the reverberations of neoliberalism is the 'domain of Aboriginality' (Walter, 2008). In the first theme, the two most visible outcomes of neoliberalism's incursions are used to demonstrate its impact. These are: the abolition of the national representative body, ATSIC, in 2005 and the Northern Territory (NT) 'Intervention' from 2007. These events, however, are the high tide markers. The broader impact is more pervasive and goes to the heart of non-Indigenous/Indigenous relations in Australia.

The second theme of resistance, endurance and survival articulates how neoliberalism's discursive and political dominance has been defied. Neoliberalism's incursions reinforced that our rights, recognition and sovereignty must not only be fought for, but once gained vigilantly protected and, too often, fought for again. Our unique post-colonial history of specifically Indigenous activism and struggle is also contemporarily pertinent. George Walter Arthur's 1880s letter to Queen Victoria asking that Tasmanian sovereignty be respected (Reynolds, 2005); the 1924 astuteness of Fred Maynard forming the first political and united Aboriginal activist group, the Australian Aboriginal Progressive Association (Maynard, 1997); William Ferguson defiantly coordinating the National Day of Mourning in 1938 in response to the lack of legislative reform for Aboriginal people in New South Wales (Horner, 1981); the work of Faith Bandler and others to ensure 
the 'Yes' vote in the 1967 referendum (Attwood \& Markus, 1999); the Aboriginal Tent Embassy in the early 1970s; and the (mostly) patient but persistent work of strong men and women such as Charles Perkins, Lowitja O'Donoghue, Tom Calma, Michael Mansell, and Mick and Patrick Dodson demanding the nation's attention through the 1980s and 1990s remain salient. This heritage of resistance underpins the emergence of the Indigenous neoliberal resistance paradigm.

\section{Rational Economic Man Comes to an Indigenous Community Near You}

For Indigenous Australians, the eras before neoliberalism's dominance were never 'the good old days'. We have to go back a lot further for that. But neoliberalism brought a new, radical era of suppression, turning the clock back for Indigenous rights in unheralded ways. In Australia, as in other Western industrialized nations, neoliberalism arrived with the perceived necessity of being part of the global market economy. Within a short period neoliberalism infiltrated social, cultural and political frameworks. The notion of citizenship was individualized to mean personal freedom to operate in the marketplace and individual accountability for success or failure. The nation-state became the neoliberal state (Harvey, 2005; Walter, 2007).

At first glance, neoliberal policy influence could be construed as rights enhancing. State efforts to build an Indigenous economic base emerged from market-related thinking that rejected neglectful paternalism in favour of participation. Individual and market-based solutions were seen as providing an incremental path for Indigenous Australia out of our socially marginalized position. The funding of Indigenous organizations, the extension of the Community Development Employment Program (CDEP) to urban areas, Indigenous business and employment programs providing tailored support for Indigenous jobseekers and enterprises, and the acquisition of land on behalf of dispossessed Aboriginal peoples were policies conceived and executed within this framework.

But the neoliberal influence begun under the Hawke and Keating governments of the 1980s and early 1990s was radically accelerated from 1996 under the Howard regime. In this less benign era, neoliberal ideology moved from influence to orthodoxy. And orthodoxies brook no adaptations. Disregarding the lack of fit between Indigenous lives and rights and a free market paradigm it was Indigenous Australia that had to alter to fit the template; rational economic man was not open to Indigenization. Unreconstructed ideologies and discourses of market forces and market economics were applied to almost every aspect of Indigenous life. Whatever the issue, the market economy or market solutions were the answer.

\section{A Pivotal Resistance: No Turning Back}

Indigenous Australians, as a whole, were not naïve about what the extreme neoliberalism of the Howard government might mean. We all expected the struggle to get harder. Anticipation of harder times, however, was quickly replaced by a harsher reality. In May 1997, the federal government declined to take part in the first National Sorry Day, despite the tabling in parliament of the 700-page Bringing Them Home report into the 'Stolen Generations' of Aboriginal children (Human Rights and Equal Opportunity Commission, 1997). The Howard government publically disagreed with the figures in the report and rejected the idea of a government apology, responding with a 'defensive, mean-spirited suspicion' 
(Manne, 2001, p. 38). Howard, himself, later argued that many Indigenous children 'were taken in circumstances where under today's laws they would be regarded as being properly and lawfully taken from their families in the interests of their own protection' (quoted in Maddison, 2008, p. 12). The Howard government also opposed the Australian High Court's Wik decision ${ }^{2}$ which, recognizing the common law principle of coexistence, placed 'native title' on an equal footing with pastoral interests. The response was a 10 Point Plan to wind back, or extinguish, native title by amending the Native Title Act 1993 (Cth) (Australians for Native Title \& Reconciliation, 2005).

The tenor of the changed relationship was, therefore, clear very early in the Howard government's first term. The first Indigenous response was a protest event during Howard's address to the Australian Reconciliation Convention in May 1997. Around 100 conference delegates made their resistance physical, standing up and turning their backs on the Prime Minister during his address. Television footage showed Howard as shocked and enraged. The media were also taken aback at this public display of defiance. Indigenous protests were not uncommon, but such an open rebuke at a formal event constituted uncharted territory. The incident was emphasized by the fact that convention attendees had been hand picked as 'good' Aborigines, not radical activists.

The turning-of-backs event was pivotal for three reasons. First, it marked a distinct new phase in Indigenous resistance; one where Indigenous people were confident enough to meet disrespect with disrespect. In this way, it contributed to the distinctive protest repertoire initiated by Indigenous activists and/or their supporters. Second, it marked the end point of any faith among Indigenous groups that a fruitful, respectful relationship could be forged with the Howard government. Open resistance was declared. Third, it likely was a catalyst to the harshness and personality-driven attacks on all matters Indigenous during the Howard years. Indigenous people largely regarded the back-turning as an appropriate response to the active reversal of Indigenous rights but the protest action was politically not well received. It might even have been at this early point that the 'end' of ATSIC began. Public addresses by Howard at Indigenous conferences, and indeed federal support for large discussion gatherings of Indigenous people more generally, certainly ceased from this point.

\section{Politics, Think Tanks, and Big Events}

A unique aspect of the neoliberal undermining of the tenuous Indigenous autonomy was its cast of players. The Howard regime was supported, and in many cases led, by pre-skirmishes orchestrated by the media, social commentators and neoliberal think tanks, such as the Centre for Independent Studies (Hughes \& Warrin, 2005; Hughes, 2007) and the Bennelong Society (Howson, 2004a, b). I propose that the specifics of the Howard era neoliberal/Indigenous interactions were neither random nor the unfocused outcome of the broader market forces ideology. Rather, the evidence indicates that the Howard government strategy in Indigenous affairs was deliberate and incremental in its unfolding. Moreover, while the aim of improving Indigenous life circumstances was not entirely absent, neither were these goals at the forefront. Indeed, the ambitions of some participants were patently neither benign nor altruistic. There appears to have been a coordinated effort to undo previous positive changes in the state's relationship with Indigenous people by the progressive marginalization of Indigenous organizations, communities and spokespeople. This power play was matched with a concerted attempt to quash dissent from Indigenous 
groups, spokepeople and their supporters. The Howard regime was overt in its claim that under its 'new' Indigenous policy direction a rights agenda had no place. Politically, this manoeuvring culminated in the elimination of the political face of Indigenous power, ATSIC, in 2005. As a further demonstration of power, Howard launched the NT Intervention in 2007.

Analyses of these two 'big events' need context. I, like many other Indigenous people in Australia, do not support what the representative arm of ATSIC became, nor the 'big man' politics played out within its structures. Manifest failings of good governance, democratic process and transparent practices were obvious, although not all ATSIC representatives were culpable. What I am critiquing is the systematic undermining, by both government and neoliberal think tanks, of ATSIC's representative capacity and the forum and voice of influence for Indigenous Australia within the political realm that it provided. Similarly, with the NT Intervention, there is no doubt that life in many Indigenous communities in the Northern Territory was, and mostly remains, catastrophically impaired by chronic overcrowding, poor or non-existent infrastructure, heavy burdens of disease, and interpersonal relationships riven by alcohol and other substance abuse. Aspects of the Intervention, such as child health checks and even welfare quarantining in some cases may turn out to have positive long-term outcomes. Additionally, the Intervention immediately exposed the manifest inadequacies of funding for infrastructure, housing, schools, roads, water, food supplies, and health services. But the 'crisis' was not new. Rather, family and sexual abuse had been the subject of reports and submissions by Indigenous and non-Indigenous advocates for change for thirty years prior to 2007. In summary, the following is not a denial of evident problems but an analysis of the coercive use of power and the motivations driving these events.

\section{ATSIC Goes Under}

The Hawke Labor government created ATSIC in 1990 as a semi-autonomous national Indigenous representative body to which it could devolve responsibility for some Commonwealth Indigenous programs and policy areas. ATSIC had sixty elected regional councils and a twenty-member board of commissioners, which comprised the representative arm of the organization. Alongside this sat a separate bureaucracy designed to implement policy, with a significant workforce, many of whom were Indigenous. The rapidly changing political terrain from the mid-1990s brought ATSIC and its operations into conflict with the Howard government and neoliberal advocates in the media. ATSIC was targeted as representing all that was wrong with policies of Indigenous self-determination. ${ }^{3}$ As Hal Wootten (2002) remarks, under the new policy framework, self-determination moved from being the 'solution' to the 'problem' of Indigenous Australia.

The breadth of anti-ATSIC sentiment makes it hard to unpick the impact of its failings. But what is clear is that the organization was systematically scapegoated for all Indigenous policy failure and the intractability of the dire socio-economic and socio-cultural position of Indigenous Australians. Criticism of ATSIC was incessant despite the responsibility for Indigenous health, education, justice and welfare - the key indicators of Indigenous disadvantage - resting not with ATSIC but with the Commonwealth and/or State governments (Walter, 2007). Indeed, on coming to office in 1996, the Howard government had specifically reclaimed responsibility for Indigenous health. In 2004, ATSIC was 
condemned when Howard declared that the 'the experiment in separate, elected representation for indigenous people has been a failure' (Shaw, 2004). As the then Minister for Indigenous Affairs, Amanda Vanstone, argued, there was no need for separate representation, because Aboriginal people 'vote in elections and they do have elected representation, that's their local member ... Indigenous Australia will have in a sense a separate voice, but it will be one selected on merit' (Australian Broadcasting Corporation (ABC), 2004).

Neither is it a coincidence that, in what Jon Altman (2007) calls the 'Influence Wars', the think tank and media commentary came from those aligned with neoliberalism. Bennelong Society member John Howson was vocal in demanding the abolition of ATSIC. Writing articles with titles such as 'With ATSIC gone we can address the real problems of Indigenous people' (2004a) and 'Abandoning ATSIC not enough to bring about needed change' (2004b), Howson focused on ending separate representation as a necessary prelude to Indigenous 'integration'. Nothing but the complete shutdown of ATSIC was enough (Johnstone, 2004).

\section{Protest and Resistance: ATSIC}

The abolition of ATSIC and, more particularly, the failure of the Howard regime to replace the body with another representative voice, did not pass without protest. The resistance, however, was neither as vehement nor as coordinated as it might have been, for two main reasons. The first concerns the imbalance in media focus. A perusal of media reports of the time might lead to the conclusion that there was virtually no Indigenous protest. The more accurate story, however, is that the voices that did protest were muted by limited reporting. While the case for the dismantling of ATSIC was made loudly and repeatedly in multiple political and media forums, the case against was barely given oxygen. Nevertheless, Indigenous media, such as the National Indigenous Times, ran numerous stories challenging the dominant discourse. Criticism also came from Indigenous academics, such as Steven Hagan (2005) who protested the case in public opinion forums, and Larissa Behrendt (2005) who argued it was ATSIC's vocal criticism of government policy, its funding of native title litigation and its ability to lobby in the international arena and embarrass the federal government on its human rights record that were the real impetus for abolishment. ATSIC members also protested loudly and in some cases through the courts. Geoff Clark, as Chair of ATSIC, fought a long-running, and eventually successful, legal battle on the legality of his suspension from his position (National Indigenous Times, 2005).

The second reason for a fizzle rather than a bang was that many Indigenous people had lost faith in ATSIC leadership. The considerable failings of powerful figures within ATSIC played directly into the hands of those who were determined to bring the organization undone. The various exploits of Chair Geoff Clark and Deputy Chair 'Sugar' Ray Robinson received widespread media attention and examples of cronyism and nepotism were well known. The first Chair of ATSIC, Lowitja O'Donoghue, at Indigenous talks on a new representative body, recently articulated her anger at the damage done by such behaviour (ABC, 2009a). Reluctance to publicly support a tainted organization was bolstered by the - vain as it turned out - hope that the removal of ATSIC might increase the influence of their own organizations. The so-called ATSIC replacement - the handpicked National Indigenous Council - also blunted Indigenous protest by placing people in the culturally difficult position of publicly criticizing their own. 


\section{The Northern Territory Goes Under}

The last 'big event' under the Howard regime was the announcement in July 2007 of the Northern Territory Intervention. The Northern Territory, where a large proportion of the Indigenous population live in discrete, often remote, communities is, unlike the Australian States, retained within the federal government sphere of direct involvement. The Indigenous population in these communities lives in circumstances of extreme overcrowding (up to twenty people living in one small house), often without basic infrastructure such as usable roads, secondary schools for burgeoning young populations and negligible economic options (Walter, 2008). All-encompassing poverty, a high burden of disease, high early mortality rates, high rates of alcohol and drug abuse and dependence, and suicide among young people are common features. What they often do have is native title to their ancestral lands, strong, active cultural traditions and a fierce determination to retain their rights to an Aboriginal way of life.

The NT Intervention has a different neoliberal aetiology to the abolition of ATSIC, but similar underpinnings. It was heralded by Prime Minister Howard as a 'crisis response' to the Northern Territory government's lack of response to the Ampe akelyernemane meke mekarle: Little Children are Sacred report on child abuse within Aboriginal communities (Wild \& Anderson, 2007). More cynical observers, of which I am one, regarded it as a desperate political ploy to centre race at the forthcoming election in which opinion polls were firmly against Howard. Indeed, the strategy has remarkable similarities to the votewinning actions against asylum seekers prior to the 2004 election (see Tazreiter, this issue). I am less cynical about the motivations of the minister responsible, Mal Brough. My reading is of a commitment to improvement in Indigenous Australia but with little notion of Indigenous rights. The need for action was likely also filtered via the standpoint of Brough's own military background.

The form and action of the Intervention were breathtaking in all negative senses of the term. First, it was announced and enacted over a period of just a few days. Second, its first action was the occupation of Indigenous communities by Australian military forces, with the stated aim of 'stopping' endemic child sexual abuse. The Intervention rapidly rolled out across Indigenous communities in the Northern Territory throughout the second half of 2007. The hastily passed supportive legislation provided an extraordinary range of measures directly impacting on seventy-three Indigenous communities. These included: alcohol restrictions, quarantining of half of the welfare payment of all recipients; health checks for all children; enforced school attendance; compulsory federal government acquisition of the lease of the affected communities for five years; cancellation of community CDEP programs; and cancellation of the Aboriginal land permit system (see Altman \& Hinkson, 2007 for discussion). To enable the Indigenous-specific implementation of this raft of restrictions the Racial Discrimination Act 1975 (Cth) was suspended. This left those people most adversely affected deprived of the option to object to the abrogation of their rights.

Despite its suddenness of execution, the NT Intervention was also preceded by a pattern of neoliberal think tank input and media commentary. The Centre for Independent Studies (CIS) whose stated purpose is 'to be actively engaged in support of a free enterprise economy and a free society under limited government' was a central player. The planks of the Intervention correlate much more strongly with CIS policy exhortations than the Little Children are Sacred report. CIS has issued a cascade of polemics on Aboriginal 
policy, usually authored by Senior Fellow Helen Hughes. Key features are an ongoing argument for the removal of the permit system, the introduction of individual property rights over communal ownership and calls for the closing down of 'unviable' communities and the dismantling of 'separatist' policies (Hughes, 2007; Hughes \& Warrin, 2005).

Reducing child sexual abuse is, of course, an incontestable aim. But critics (and there are many) point to the range of elements in the NT Intervention that appear to have little to do with this stated objective. Instead, the Intervention was, and is, perceived as an attempt to 'normalize' the Aboriginal population by replacing concerns for custom, kin and land with the neoliberal individualist aspirations of private home ownership, career and self-improvement (Hinkson, 2007, p. 6). The welfare quarantining provisions and compulsory acquisition of Aboriginal lands explicitly attempt to enforce the Indigenous citizen to be the good citizen of the free market. Indeed, the NT Intervention might be seen as a dramatic State reaction to Indigenous people's ongoing resistance to being moulded into rational economic man. Indigenous people in the Northern Territory needed to be forced to be free.

\section{Protest and Resistance: The NT Intervention}

Resistance to the Intervention has a different trajectory to that relating to ATSIC. The initial Indigenous reaction at its suddenness and extent was numb shock. But earlier experiences of the Howard government's Indigenous policy direction meant shock quickly became anger. The NT Intervention has been no rout of Indigenous autonomy. But resistance and survival strategies required innovative and multiple responses.

The discourse of crisis intervention to 'rescue' abused children labelled any refutation of the Intervention as support for child abuse or for outdated regimes of 'failed' policy. This discursive device did not, however, mute the voices of protest nor restrict such protest to a few individuals or groups. Indeed, anger at the Intervention has not been dimmed by either the passage of time or a change of government. If anything, the protests and calls for change have grown stronger as the official rationale for the Intervention is more fully exposed as unsubstantiated. Criticism has come from media, church and secular groups, Indigenous and non-Indigenous commentators, and from national and international sources. These are too widespread to be named individually but include Aboriginal activists and scholars such as Lowitja O'Dohoghue, Larissa Behrendt, Mick Dodson and Ian Anderson; international human rights groups such as Amnesty; specifically formed protest groups such as the Aboriginal Rights Coalition; the Prescribed Areas People's Alliance (made up of people directly affected by the NT Intervention); the Stop the Intervention Collective; the Working Group for Aboriginal Rights; and a revival of the organization Women for Wik. The activities and protest strategies of these groups vary. The Aboriginal Rights Coalition, for instance, called a national conference in Sydney in May 2008 while Women for Wik provides an information network for over 2,000 subscribers.

At the community level, protest has also been strong. Elders from affected Northern Territory communities have attended, and continue to attend, protest rallies in cities and towns around Australia. In March 2009, 25 Elders from Groote Eylandt visited the state of Victoria to highlight the impact of the Intervention on their community (Women for Wik, 2009). The Aboriginal Tent Embassy in Canberra (Australia's capital) is an ongoing potent symbol of resistance in this struggle. Established in 1972, the Tent Embassy has 
been torn down, raided, and declared illegal on a regular basis and these attacks continued into, and through, the Howard years. But it remains a presence, a physical act of defiance, sovereignty and a rallying point. On 4 February 2009, it was again the centre for a rally of more than 400 people protesting against the NT Intervention and demanding the reinstatement of the Racial Discrimination Act. Hundreds of people later converged on the lawns outside Parliament House (National Indigenous Times, 2009).

Resistance has also been taken to the national and international stages via legal action. In 2008 as one of the 73 prescribed communities, the Maningrida traditional owners and the Bawinanga Corporation challenged in the High Court of Australia the validity of the mandatory takeover of the town's lease on the basis that the property was not acquired on 'just terms'. The concern was the need to protect sacred sites, traditional hunting and gathering rights and the assets of the community and its organizations. The case was rejected by the High Court in a 6:1 majority judgment that held that the laws supporting the mandatory acquisition of leaseholds did provide for proper compensation (Gartrell, 2009). Just what that proper compensation is remains undefined. Justice Michael Kirby, in his last case before retiring from the High Court, was the only dissenting voice, arguing that the case should go to trial. The decision was not accepted without resistance, with mainly Aboriginal protesters pushed into the High Court in Canberra to verbally and physically challenge the ruling.

The decision also led to formal complaints being taken to the United Nations. Aboriginal people from Alice Springs are arguing that the Intervention was, and is, racially discriminatory and that the underpinning laws breach Australia's international obligations under the Convention on the Elimination of Racial Discrimination. In March 2009, the suspension of the Racial Discrimination Act was named a potential human rights violation under the UN's International Covenant on Civil and Political Rights of which Australia is a signatory. Lawyers from the Melbourne-based Human Rights Law Resource Centre have formally briefed UN officials in New York, forcing the federal government to send representatives to present its case (Arup, 2009).

So, have these protest actions been effective? The signals are mixed and an overall outcome is difficult to judge given that the Intervention is a broad grouping of disparate policy directions, some of which have changed significantly since the original legislation. For example, the current Minister for Indigenous Affairs, Jenny Macklin, confirmed in March 2009 that funding for law and order, alcohol and pornography measures will be extended for three years. These measures include an additional sixty-six Australian Federal Police positions in the NT, including at least six specialist officers in the child abuse taskforce, the construction of five permanent police stations and the continuing night patrol services in eighty-one communities, twenty-two safe houses and funding extensions for an Aboriginal interpreter service and legal assistance service providers (ABC, 2009b). While these aspects are part of the Intervention, few Indigenous or nonIndigenous people would not support them. On the other hand, however, the forced quarantining of welfare payments is still in place and the suspension of the Racial Discrimination Act remains current. While Minister Macklin foreshadowed that legislation to reinstate the Act would be introduced late in 2009 this had not occurred. It now appears that welfare quarantining will remain but with its discriminatory impact legally negated by being extended more broadly across disadvantaged communities in Australia, many of whom just happen to be largely inhabited by Aboriginal people $(\mathrm{ABC}, 2009 \mathrm{c})$. 


\title{
The Domain of Aboriginality: An Indigenous Theoretical Frame
}

The analytical frame for the theoretical interpretation of the impact of neoliberalism and Indigenous resistance to it is the domain of Aboriginality (Walter, 2009). This theoretical structure allows an analysis of the broader contours of the reach of neoliberalism into Indigenous lives and the resistance to the developing hegemony. The domain of Aboriginality refers to lived experience, not ethnicity, and is comprised of intersecting and intertwined layers, although four thematic clusters can be identified, as described below.

\section{Socio-economic Position}

Socio-economic position refers to the undisputed position of Indigenous people, regardless of region, background, or location, as the poorest and most disadvantaged across all socio-economic indicators. Three factors make up this cluster: (i) material poverty based on Indigenous exclusion from a relative share of society's resources and opportunities; (ii) the resultant inherited, population-wide socio-economic deprivation that accumulates across the life chances of Indigenous individuals, families and communities; and (iii) the continuing explicit and implicit Indigenous exclusion from material privilege. Aboriginal people are expected, and expect, to be poor.

\begin{abstract}
Absences
Indigenous Australia is largely missing from Australia's view of itself, except as usurpable cultural icons. This invisibility is conceptualized as a cluster of four absences. First and second, Indigenous people are spatially and socially separated. Nearly three-quarters of us live in regional and urban areas, but Indigenous lives remain separated spatially and socially in almost all spheres from those of non-Indigenous people in the same geographic location. Most non-Indigenous people live their lives within an Indigenous-free zone: an option not available to most Indigenous Australians. Third and fourth, these separations are magnified by the physical and figurative absence of Indigenous Australia/ns from spheres of influence at all levels, including the nation-state's concept of itself and the business of state.
\end{abstract}

\section{Disregard}

This national invisibility as part of Australian life is juxtaposed with an over-visibility as social problems. The tenor of non-Indigenous/Indigenous relations is built on a normalization of disrespect. Most Australians would vehemently deny being racist, but a constant, casual denigration of Aboriginal people is twisted into the daily fabric of the nation's conversations. Everyday discussions of the 'deficits' of Indigenous people, culture and lifestyle provide a circular rationale for inequality. Despite physical proximity, Indigenous Australia is understood mostly via a media lens and resultant public gaze that is intrusive, judgemental, but personally distant.

\section{Dispossession}

Indigenous Australia has been dispossessed of land, culture and, in many cases, family. Dispossession of land and culture continues via the perpetually subservient position 
of Indigenous rights under the entitlement demands of non-Indigenous Australia. We are also dispossessed of optimism: there exists an Indigenous fatalism towards a poor deal. The dramatically circumscribed life chances and the hard daily reality of this generation and previous ones have become a normalized aspect of Indigenous life. We are too often dispossessed of a conception of a different future.

\section{Gazing through a Neoliberal Lens: A Peripheral, Unviable Group of Individuals}

While it has been argued that in classic liberalism the duality of the individual and social categories of rights leaves no conceptual space for group rights (Kymlicka, 1995), neoliberalist ideology takes such limitations much further. Individualism extends to conceptions of 'equality'. Inequality is regarded as socially functional in that the race(and gender-) neutral individual is encouraged to earn rewards and disadvantage is an incentive to change individual flawed behaviours, attitudes and values. In this final section, the domain of Aboriginality is the frame for exploring how neoliberalism responded to the specific rights and socially and politically inequitable position of Indigenous Australia. The contradictions and subtexts illustrate how neoliberalism met Indigeneity; and, more crucially, how Indigeneity met neoliberalism.

\section{Loading up the Burden of Disregard onto the Burden of Poverty}

Individualized neoliberalism is unable to explain embedded Indigenous socio-economic disparities. In Australia, this conceptual difficulty is overcome by a 'blank slate' discourse whereby it is assumed (without evidence) that identifiable barriers to equality, such as discrimination and racism, are long removed. This allows debate to be blinkered to anything but the 'now' and references to past discriminations are labelled as 'unhelpful' or 'black armband'. In the case of the NT Intervention, the 'national emergency' rhetoric of immediate and current crisis precluded an examination of past governmental actions and inactions (Hinkson, 2007). Deeming all Australians now equal, this discourse renders invisible the privilege of those outside the domain of Aboriginality and allows the present-day reverberations of multi-intergenerational individual, family and communal deprivation to be portrayed as whinging self-pity.

There is a dissonance here. Individualism is applied to Indigenous Australia in racially grouped formation. The neoliberal discourse causatively links individual choices, in particular around labour market participation, or lack of it, as the cause of inequality. Reducing individual's welfare dependency is perceived as the silver bullet solution. Yet, for Indigenous people, these behavioural choices are portrayed as racially aligned selections, with culture wound into the causality. In the neoliberal-inspired overhaul of the Australian welfare state of the early 2000s, Indigenous welfare dependency became a hot political topic. The high reliance of Indigenous people on income support payments was recast from indicating ongoing poverty, marginalization and exclusion to indicating social and cultural dysfunction. Media reports using faux Aboriginalisms such as 'sit down money' ensured the discourse was racially loaded. Practically, the new neoliberal take rationalized Indigenous-specific behavioural change policy instruments, such as Shared Responsibility Agreements in 2005, the blanket welfare quarantining of the NT Intervention in 2007 and the 2008/2009 child school attendance requirement for the 
receipt of parental income support introduced into a dozen communities, nearly all of which are Aboriginal.

The normalization of the disregard in which Indigenous people are held in Australia means that racially specific policies are not publicly condemned as racist or unfair. Open expression of that contempt has indeed been legitimized during the neoliberal phase. The normalization of Indigenous exclusion from privilege is also played out in resentment of a lack of dire poverty among Aboriginal activists. Not being poor is perceived to negate authenticity and an individual's or groups' rights to advocate. For example, Aboriginal activist Mick Dodson was called hypocritical in his rejection of calls to privatize Indigenous communal lands, because he was a homeowner (ABC, 2005). It is difficult to imagine the attribute of deprivation demanded of non-Indigenous campaigners against inequality such as Tim Costello, who is well known in Australia as a social welfare campaigner.

\section{Resistance and Oppositions: Overcoming the Burdens}

As in past times, in spite of, and sometimes because of, constant messages - both explicit and implicit - to the contrary, pride in culture, pride in ancestry, belief in self, family, community, place and country is celebrated. An example is the rising popularity and influence of the annual Garma Festival held in the Northern Territory in Yolngu country, near Nhulunbuy. Garma is organized by a not-for-profit Aboriginal charitable corporation and as such it is independent from government funding and moulding (Yothu Yindi Foundation, 2009). Garma is increasingly drawing Indigenous and non-Indigenous people from around Australia to celebrate Yolngu culture specifically and Indigenous cultures more generally. The annual Deadly Awards to Aboriginal and Torres Strait Islander Achievers in the fields of Music, Sport, Entertainment and Community provide another example of growing celebration of Indigeneity, which deliberately resists and protests against the 'deficit' public and political portrayals of Indigenous people. Beginning as a community initiative in a Co-op in the Sydney suburb of Redfern in 1995, in 2008 the Deadlys were hosted at the Sydney Opera House and received wide media coverage (VIBE Australia, 2009).

Denigration of Aboriginal people and culture has also been rejected by many nonIndigenous people. The hundreds of thousands of Australians who expressed their opposition to the Howard regime's policies by participating in the People's Walk for Reconciliation in 2000 demonstrate that the neoliberal hegemony is incomplete. In Sydney alone, more than a quarter of a million people walked across the Harbour Bridge. And while three government ministers - Phillip Ruddock, John Herron and Joe Hockey - did join the march, a leaked document revealed a cabinet decision to ban other ministers from attending (Australianpolitics.com, 2000). Aware of the corrosive legacy of neoliberal discourse, the organization Reconciliation Australia recently launched a series of advertisements that challenge widely held stereotypes of Aboriginal and Torres Strait Islander peoples as substance abusers, welfare dependents and criminals. The blog comments attached to the $\mathrm{ABC}$ news story strongly suggests, however, that such a campaign has a mighty task in front of it (ABC, 2009d).

\section{Dispossessing the Dispossessed is Easier if they are Out of Sight and Mind}

Indigenous denigration is undimmed by the fact that the vast majority of non-Indigenous Australians do not know any Aboriginal people. The unremitting political and media focus 
on Indigenous problems allows the Indigene to be examined dispassionately but judgementally. Non-Indigenous Australians, including senior academics and policy makers, almost invariably discuss Aboriginal people and problems in terms of 'they', never 'us'. Our Australianness is differentiated and the complexity of the Indigenous position in Australia, as demonstrated theoretically through the domain of Aboriginality, is perceived as a singular 'issue'.

The Indigenous absence from arenas of political or social power and the nation's self-identity mutes different narratives and allows Indigenous issues to be viewed as peripheral to 'Australian' concerns. This absence allows a causative conflation of cultural practices with the social, cultural, political and economic environments in which Aboriginal people live their lives. The resultant well-used neoliberal discourse holds Indigenous culture as a barrier to improved life circumstances, privileging solutions based upon cultural change; framed in terms of replacing 'unproductive' and dysfunctional Indigenous culture(s) with a marketized one. The banner of the free market legitimizes the ongoing dispossessions of land, autonomy and hope.

That the rhetoric and the reality do not match remains largely unnoticed. The opening up of Northern Territory communities to 'market forces' as a result of the NT Intervention and the cancellation of the permit system, journalist Paul Toohey (2009, pp. 14-18) claims, will turn ugly slums into towns 'with modest, functioning businesses - motels, resorts, fuel stations and tours with clean, liveable homes for raising children'. This utopian vision, however, is not on the immediate horizon. Another report in the same newspaper a fortnight later noted that, one year on, the 'immediate' funding response to the gross housing shortage in many Indigenous communities is being spent, but no houses have yet been built (Rothwell, 2009, p. 11). And the November 2008 statement by Labor Minister Macklin that communities not prepared to sign leases would get no houses does not suggest much change in approach. For, Aboriginal communities hardened by the many broken policy promises of the past are averse to giving up control of their land via a forty-year lease (Howard's version was for ninety years) for the promise (as yet undelivered in any community) of housing.

\section{Opposition and Resistance: Fighting for Land and Survival}

Indigenous protest and resistance in Australia has a long history (see Attwood \& Markus, 1999; Clark, 2008) and is often conducted against huge pressures to desist. Contemporaneously, such resistance is manifested in the defiant resistance to coercion by the Tangentyere Council, an Indigenous group with responsibility for the Aboriginal town camps (among other things) near Alice Springs. As from 2007, as part of the NT Intervention, despite massive political pressure, ever increasing promises of funding, an antagonistic media and formal threats to disband the council, Tangentyere has refused to sign leases with the Northern Territory government. The Council has consistently stated that it will not relinquish the hard-won control of Aboriginal lands for what should be their right as Australian citizens: a decent living environment. Arguing instead for a twenty-year lease and the retaining of Council autonomy, executive director William Tilmouth stated that while he had no illusions about camp conditions, the issue was about people standing up and keeping what they had, however little. He stated: 'Where do you go once you get evicted from a town camp? You ultimately end up in the bush living under trees and in humpies and car bodies' (ABC, 2008). At the time of writing the leases for town camps 
around Alice Springs (in the NT) had just been compulsorily acquired by the Rudd Labor government (ABC, 2009e).

While the Tangentyere Council has fought to keep possession, for other Aboriginal peoples the battle is about regaining what has been taken. In 2003, the 218 Indigenous family groups of the Noongar population lodged a land claim with the Federal Court in Perth, Western Australia (WA). This 'Single Noongar Claim' combines other registered and unregistered claims covering the traditional Noongar lands in the south-west corner of WA. On 19 September 2006, the Federal Court of Australia ruled that the Noongar people still had a connection with the land and had native title in the metropolitan area of Perth. The decision did not affect current freehold title, but allowed the Noongar people to use the area for traditional purposes such as hunting and maintaining and preserving important sites (ABC, 2006). Subsequently, the West Australian government and the Commonwealth government appealed against the trial judge's decision and in April 2008 the Full Federal Court overturned it (Buckley-Carr, 2008, p. 2). The matter is now back in the Federal Court.

Opposition to the plethora of continued Indigenous dispossessions in contemporary Australia is enacted at a significant risk, especially in neoliberal times. As an academic working in both an Indigenous unit and in a mainstream department during this period I can attest to the feeling of professional risk attached to publicly raising questions about the neoliberal policy direction. While Indigenous spokespeople who did not tow the political line were especially targeted, non-Indigenous people were also in the firing line. Outspoken critics of government policy such as former Governor General William Deane found themselves incurring significant public (and no doubt private) political disfavour. And research centres such as the Centre for Aboriginal Economic Policy Research at the Australian National University reported growing levels of pressure and threats and eventual withdrawal of funding over its research findings, especially during the final Howard government term (Altman, 2007).

\section{Conclusion: We're Not in 1996 Anymore}

Neoliberalism, as a spectacularly discredited ideology and policy framework, now has its own problems, and for the excesses committed under its individualized 'wealth creation and maximization' moral code we will all - black and white - pay. From an Indigenous perspective, the central role of neoliberalism in Australia over the last decade or so has been the further embedding of the hegemony of white privilege (Gale, 2005). The negative impact on Indigenous lives and rights was subsumed in ideological fervour. We were a convenient borderlands group for experimental policy without the risk of political consequences. The pillorying of Indigenous peoples also fitted neatly into the nationalistic discourses developed to sooth the distress in the non-Indigenous heartlands of those losing privilege and status in a market-forces state.

Whether there has been, or will be, a reworking of neoliberal principles and presumptions under a Rudd or subsequent federal governments is unclear. The NT Intervention remains in place, albeit with some minor modifications, and as yet there is no national Indigenous political voice, although work towards this aim has now begun (Australian Human Rights Commission, 2008, 2009). And the neoliberal think continues. It is hard to know how to react when reading an Access Economics report stating that increasing Indigenous life expectancy would be 'good for the economy' and that closing gaps in life expectancy, 
labour force participation and productivity over twenty years would net higher GDP growth and thus higher living standards for all Australians. Access Economics is no doubt well intentioned, but reducing the terrible burden of disease borne by Indigenous Australia to economics and GDP dimensions should be shocking to the nation - but it is not.

Regardless, Indigenous Australia itself has changed. Indigenous resistances to the neoliberal hegemony have radically altered our relationship with the nation-state. While the Indigenous struggle against dispossession, absence, deprivation and disregard have always reflected our culture, our story and our place, a paradigm shift has occurred. A new level of Indigenous activism emerged via the lessons learned from the incursions of neoliberalism from the mid-1990s to the present. We are no longer as naïve or as willing to believe in incremental or evolutionary change, or that good intentions are enough, or that being patient will work in our best interests. Surviving has also led to new ways of seeing things, less orthodoxy, more voices, less trust and more determination. Neither are we willing to go back to the way it was. Despite the apology, the main message from the Rudd government to Indigenous Australia is that it is business as usual; resuming where Labor left off last decade. But it is not 1996 anymore. And we are more than ready to keep fighting.

\section{Notes}

1. The term Indigenous peoples is used here when Aboriginal and Torres Strait Islander peoples are meant and the more specific term 'Aboriginal' used when the context is Aboriginal specific. Aboriginal peoples make up around 90 per cent of the Indigenous population, with around 6 per cent being Torres Strait Islanders and the remaining group Aboriginal and Torres Strait Islander.

2. Wik Peoples v. Queensland [1996] HCA; (1996) 187 CLR 1.

3. While previously policies were labelled self-determination, just what this term meant or how selfdetermination was embodied in those policies was never clarified and Indigenous advocates argue that selfdetermination cannot be deemed failed policy because it was never actually instituted (pers. comm. with Sarah Maddison, $c$. February 2009).

\section{References}

Altman, J. (2007) Indigenous Affairs Today: The 'Influence Wars' and the Attempt to Silence the Social Sciences, Topical Issue No. 01/2007 (Canberra: Centre for Aboriginal Economic Policy Research).

Altman, J. \& Hinkson, M. (Eds) (2007) Coercive Reconciliation: Stabilise, Normalise, Exit Aboriginal Australia (Melbourne: Arena Publications).

Arup, T. (2009) United Nations to query Australia on possible human rights breaches, The Age, 13 March. Available at http://www.theage.com.au/national/united-nations-to-query-australia-on-possible-human-rightsbreaches-20090312-8wid.html (accessed 13 March 2009).

Attwood, B. \& Markus, A. (1999) The Struggle for Aboriginal Rights: A Documentary History (Sydney: Allen \& Unwin).

Australian Broadcasting Corporation (ABC) (2004) Vanstone causes stir with 'apartheid' comment, Lateline, Available at http://www.abc.net.au/lateline/content/2004/s1089303.htm (accessed 12 February 2009).

Australian Broadcasting Corporation (ABC) (2005) Mick Dodson in his place, Mediawatch, Available at http://www.abc.net.au/mediawatch/transcripts/s1478406.htm (accessed 12 February 2009).

Australian Broadcasting Corporation (ABC) (2006) Nyoongar people win native title over Perth, ABC News Online, Available at http://www.abc.net.au/news/australia/wa/kalgoor/200609/s1744596.htm (accessed 12 February 2009).

Australian Broadcasting Corporation (ABC) (2008) Increasing Indigenous life expectancy 'good for economy', ABC News Online, Available at http://www.abc.net.au/news/stories/2008/09/30/2377696.htm (accessed 12 February 2009). 
Australian Broadcasting Corporation (ABC) (2009a) New Indigenous body within months, ABC News Online, Available at http://www.abc.net.au/news/stories/2009/03/11/2513128.htm (accessed 30 March 2009).

Australian Broadcasting Corporation (ABC) (2009b) Intervention moving into sustainable phase: Macklin, $A B C$ News Online, Available at http://www.abc.net.au/news/stories/2009/03/22/2522917.htm (accessed 30 March 2009).

Australian Broadcasting Corporation (ABC) (2009c) Welfare quarantining to go national, ABC News Online, Available at http://www.abc.net.au/news/stories/2009/11/25/2752768.htm

Australian Broadcasting Corporation (ABC) (2009d) Campaign tackles anti-Indigenous prejudice, ABC News Online, Available at http://www.abc.net.au/news/stories/2009/03/12/2514092.htm (accessed 30 March 2009).

Australian Broadcasting Corporation (ABC) (2009e) Government delivers Town Camp ultimatum, ABC News Online, Available at http://www.abc.net.au/news/stories/2009/03/23/2523722.htm (accessed 30 March 2009).

Australian Human Rights Commission (2008) Building a Sustainable National Indigenous Representative Body - Issues for Consideration (Sydney: Australian Human Rights Commission).

Australian Human Rights Commission (2009) National Indigenous Representative Body Workshop: Summary Report (Sydney: Australian Human Rights Commission).

Australianpolitics.com (2000) 250,000 walk for Reconciliation Week, Available at http://australianpolitics.com/ news/2000/00-05-28a.shtml (accessed 12 February 2009).

Australians for Native Title and Reconciliation (2005) The Native Title Act 1993, Available at http://www.antar victoria.org.au/nta.html (accessed 12 February 2009).

Behrendt, L. (2005) The abolition of ATSIC - implications for democracy, in: Democratic Audit of Australia November 2005 (Canberra: Australian National University).

Buckley-Carr, A. (2008) Ruling on native title overturned, The Australian, 24 April, p. 2.

Clark, J. (2008) Aborigines and Activism: Races, Aborigines and the Coming of the Sixties to Australia (Perth: UWA Press).

Gale, P. (2005) The Politics of Fear: Lighting the Wik (Frenchs Forest: Pearson Education Australia).

Gartrell, A. (2009) Violent scenes at High Court after land rights decision, Brisbane Times, 2 February. Available at http://www.brisbanetimes.com.au/news/national/violent-scenes-at-high-court-after-land-rights-decision/ 2009/02/02/1233423130343.html (accessed 16 February 2009).

Hagan, S. (2005) Where to post ATSIC, Online Opinion, 14 April, Available at http://www.onlineopinion.com.au/ view.asp? article $=3339$

Harvey, D. (2005) A Brief History of Neoliberalism (New York: Oxford University Press).

Hinkson, M. (2007) Introduction: in the name of the child, in: J. Altman \& M. Hinkson (Eds) Coercive Reconciliation: Stabilise, Normalise, Exit Aboriginal Australia, pp. 307-324 (Melbourne: Arena Publications).

Horner, J. (1981) Ferguson, William (1882-1950), in: Australian Dictionary of Biography, pp. 487-488, Vol. 8 (Melbourne: Melbourne University Press).

Howson, P. (2004a) With ATSIC gone we can address the real problems of Indigenous people, On-Line Opinion, Available at http://www.onlineopinion.com.au/view.asp?article=2155 (accessed 12 February 2009).

Howson, P. (2004b) Abandoning ATSIC not enough to bring about needed change, The Bennelong Society, Available at http://www.bennelong.com.au/articles/howson6.php (accessed 12 February 2009).

Hughes, H. (2007) Lands of shame: Aboriginal and Torres Strait Islander 'Homelands' in transition (Sydney: Centre of Independent Studies).

Hughes, H. \& Warrin, J. (2005) A new deal for Aborigines and Torres Strait Islanders in remote communities, Issue Analysis, 54, pp. 1-20.

Human Rights and Equal Opportunities Commission (1997) Bringing Them Home: Report of the National Inquiry into the Separation of Aboriginal and Torres Strait Islander Children from Their Families (Sydney: Human Rights and Equal Opportunities Commission).

Johnstone, B. (2004) The White-anting of ATSIC has been brought about by the usual suspects, On-Line Opinion, Available at http://www.onlineopinion.com.au/view.asp?article=2156 (accessed 16 February 2009).

Kymlicka, W. (1995) The Rights of Minority Cultures (London: Oxford University Press).

Maddison, S. (2008) Collective Identity and Australian Feminist Activism: Conceptualising a Third Wave (Berlin: VDM).

Manne, R. (2001) The Barren Years: John Howard and Australian Political Culture (Melbourne: Text Publishing). 
Maynard, J. (1997) Fred Maynard and the Australian Aboriginal Progressive Association (AAPA): one God, one aim, one destiny, Aboriginal History, 21, pp. 1-13.

National Indigenous Times (2005) Clark sacking unfair, rules Federal Court, Available at http://www.nit.com.au/ News/story.aspx ?id=5672 (accessed 30 March 2009).

National Indigenous Times (2009) Intervention fight to go to United Nations, Available at http://www.nit.com.au/ News/story.aspx?id=16973 (accessed 30 March 2009).

Reynolds, H. (2005) Arthur, Walter George (c. 1820-1861), in: Australian Dictionary of Biography, Suppl. Vol., pp. 10-11.

Rothwell, N. (2009) Sorry state of affairs, The Australian, 13 February. Available at http://www.theaustralian.com. au/news/sorry-state-of-affairs/story-0-1111118835074 (accessed 16 February 2009).

Shaw, M. (2004) Howard puts ATSIC to death, The Age, 16 April, p. 1.

Toohey, P. (2009) Towns a lifeline for remote Aborigines, The Australian Weekend Magazine, 10-11 January. Available at http://www.theaustralian.com.au/news/nation/towns-a-lifeline-for-aborigines/story-e6fr g6nf-1111118525385 (accessed 12 January 2009).

VIBE Australia (2009) The Deadlys, Available at http://www.vibe.com.au/vibe.asp?PageID=6 (accessed 30 March 2009).

Walter, M. (2007) Indigenous sovereignty in a globalising era, in: A. Moreton-Robinson (Ed.) Sovereign Subjects: Indigenous Sovereignty Matters, pp. 155-167 (Sydney: Allen \& Unwin).

Walter, M. (2008) Lives of Diversity: Indigenous Australia (Canberra: Academy of the Social Sciences in Australia).

Walter, M. (2009) An economy of poverty: power and the domain of Aboriginality, International Journal of Critical Indigenous Studies, 1(2), pp. 2-14.

Wild, R. \& Anderson, P. (2007) Ampe akelyernemane meke mekarle: Little Children are Sacred - Report of the Northern Territory Board of Inquiry into the Protection of Children from Sexual Abuse. Available at www.nt.gov.au/dcm/inquirysaac/pdf/bipacsa_final_report.pdf (accessed 16 February 2009).

Women for Wik (2009) Who are we?, Available at http://www.womenforwik.org/ (accessed 30 March 2009).

Wootten, H. (2002) Finding the future: three approaches to the problems in Aboriginal communities, On-Line Opinion, Available at http://www.onlineopinion.com.au/view.asp?article=1049 (accessed 16 February 2009).

Yothu Yindi Foundation (2009) About the Garma Festival, Available at http://www.garma.telstra.com/aboutgar ma.htm (accessed 30 March 2009).

Maggie Walter, a trawoolway woman from North Eastern Tasmania, teaches and researches the fields of critical Indigenous studies, inequality and social policy at the University of Tasmania. Recent publications include Social Research Methods (Oxford, 2010, 2nd edition) and Social Inequality in Australia: Realities, Discourses and Futures (with D. Habibis, Oxford, 2008). 